\title{
Seroprevalence of HBV and HIV Co-infection in Children in Nnewi, South-East Nigeria
}

\author{
Kenneth Nchekwube Okeke", Ifeoma Egbuonu², Ebelechukwu Francesca Ugochukwu2 ${ }^{2}$, Thomas \\ Obiajulu Ulasi ${ }^{2}$, Chukwudi Onyeaghana Okani ${ }^{3 *}$, Obiora Shedrack Ejiofor ${ }^{1}$ and Christian \\ Chukwuemeka Ifezulike ${ }^{1}$
}

${ }^{1}$ Department of Pediatrics, Chukwuemeka Odumegwu Ojukwu University Teaching Hospital, Amaku-Awka, Anambra State, Nigeria

${ }^{2}$ Department of Pediatrics, Nnamdi Azikiwe University Teaching Hospital, Nnewi, Anambra State, Nigeria

${ }^{3}$ Department of Histopathology, Chukwuemeka Odumegwu Ojukwu University Teaching Hospital, Amaku-Awka, Anambra State, Nigeria

${ }^{*}$ Corresponding author: Chukwudi Onyeaghana Okani, Department of Histopathology, College of Medicine, Chukwuemeka Odumegwu Ojukwu University, Amaku-Awka, Anambra State, Nigeria, Tel: (+234) 07030072425; E-mail: chudiokani@gmail.com

Rec date: November 12, 2017; Acc date: December 12, 2017; Pub date: December 16, 2017

Citation: Okeke KN, Egbuonu I, Ugochukwu EF, Ulasi TO, Okani CO, et al. (2017) Seroprevalence of HBV and HIV Co-Infection in Children in Nnewi, South-East Nigeria. Ped Health Res. Vol. 2 No.3:20.

\section{Abstract}

Background: Human immunodeficiency virus/HBV coinfection remains an important public health issue due to the risk of rapid progression to chronic liver disease and death. Despite the foregoing, there is paucity of data on Hepatitis among HIV-infected children receiving treatment in a tertiary hospital at Nnewi, South-East Nigeria.

Objectives: This study was carried out to determine the prevalence of HBsAg in HIV-infected and non-HIV-infected children at Nnamdi Azikiwe University Teaching Hospital (NAUTH), Nnewi, Anambra State, Nigeria.

Methods: A cross sectional case control study was carried out among 120 HIV infected and 120 non-HIV infected children. The care givers and/or children were interviewed using a semi-structured questionnaire to obtain their socio-demographic characteristics, possible risk factors for HBV transmission and HBV vaccination history. All the participating children were screened for Hepatitis B surface antigen.

Results: The prevalence of hepatitis B surface antigen among HIV-infected and non-HIV infected were $5.8 \%$ and $0.8 \%$ respectively $(p=0.03)$. Most of the children with HBV were males. The mean age of those infected with HBV was significantly higher than those without HBV infection. History of unsafe parenteral injections $(p=0.03)$ and blood transfusion $(p=0.02)$ were significantly associated with HBV surface antigen seropositivity.

Conclusion: This study has demonstrated that the rate of HBV infection among HIV infected children is higher than that of the non-HIV infected children with increased risk of HBV seropositivity from parenteral injection and blood transfusion also amongst HIV infected. Adequate screening of blood and its products before transfusion is advocated.

Keywords: HBV; Chronic liver disease; HIV-infected children; South-East Nigeria

\section{Introduction}

Hepatitis B virus (HBV) infection remains a major public health problem now a days and its rate of incidence increase day by day, with about two billion people infected worldwide and more than 340 million being chronic HBV carriers [1]. Globally, the infection causes about 600,000 thousand deaths per year mainly because of the numerous associated complications such as chronic hepatitis, cirrhosis, and primary liver cell carcinoma [1,2]. It is estimated that approximately one third of the infected individuals end up having symptoms and/or serological evidence of hepatitis infection $[2,3]$. It is also well established that the earlier in life of coming in contact with the virus the higher the risk of the infection becoming chronic. This is because they are less likely to clear the virus due to relative immunosuppression in younger children. There are no signs any symptoms up to immunosuppression. This is reported to be as high as $90 \%$ when it occurs during infancy [4].

There is significant variation in the prevalence of HBV infection among the Pediatric population year by year. In SubSaharan Africa, the prevalence of HBV surface antigen (HBsAg) is $3 \%-20 \%$, with prevalence of markers of past exposure ranging from $60 \%-99 \%$ [5]. In the West Africa sub-region, a chronic carrier rate of about $20 \%$ in children has been reported and this exceeds the $7 \%$ prevalence required for classification as hyper-endemic [6]. Studies of HBV in Nigeria have also reported high rates of the infection with prevalence ranging from $9 \%-39 \%$ [7-10]. Like HBV, HIV/AIDS is also a very important public health problem. In 2012, an estimated 35.3 million people worldwide were infected with HIV/AIDS, with an 
annual incidence of 2.1 million and a mortality rate of approximately 1.5 million deaths in 2013 [11]. More than 70\% of all these new infections occur in Sub-Saharan Africa. With regard to gender predisposition to HIV/AIDS, women are disproportionately more affected in Sub-Saharan Africa constituting about $60 \%$ of the region's infected individuals [11]. With a national prevalence rate of $3.4 \%$ and a population of 148 million, it has been shown that Nigeria has a very high burden of people living with HIV/AIDS [12,13]. Nigeria is reported to have the highest burden of mother- to- child transmission (MTCT) of HIV in the world based on its highest burden of HIV positive pregnant women [14]. This accounts for the concomitant high burden of Pediatrics HIV, with MTCT being responsible for more than $90 \%$ of Pediatrics HIV, while over 240,000 children are living with HIV/AIDS representing $15 \%$ of the African burden [14].

Due to shared modes of transmission, HIV/HBV co-infection is common [15] and up to $90 \%$ of world's HIV infected persons have biological markers of prior HBV infection (defined as presence in serum of anti HBcAb). Of these, $5 \%-15 \%$ suffers from chronic HBV infection [16]. Consequently, 2-4 million of 33 million people living with HIV globally also harbour chronic hepatitis B infection [17]. In the United States of America, up to $10 \%$ of all HIV infected individuals show evidence of $\mathrm{HBV} / \mathrm{HIV}$ co infection [18]. The population prevalence of HIV/HBV co-infection in Africa is thought to reflect the population prevalence of hepatitis $B$ surface antigenaemia ( $\mathrm{HbsAg}$ ). In Nigeria, where HBV infection is endemic, the prevalence of $\mathrm{HBV}$ infection in the general population ranges from $7.5 \%$ to $44.7 \%[19,20]$. However, few reports exist on the prevalence of HIV/HBV co-infection among the Pediatrics population. It is postulated that the prevalence will be high because of high rates of mother to child transmission of HBV which may be responsible for the highest burden of HBV infection among children less than five years of age. In Benin, Sadoh et al. documented a prevalence of $7.7 \%$ among HIVinfected children [21,22].

Co-infection with HBV/HIV itself has also been shown to be associated with increased replication of $\mathrm{HBV}$, higher serum levels of HBV DNA genome and decreased rate of $\mathrm{HBsAg}$ clearance $[23,24]$. A good number of the studies on HBV/HIV co-infection in Nigeria have been on the adult population. It is therefore of utmost importance that the burden of this coinfection in a population of Nigerian children with HIV be investigated. This will be useful in designing intervention programs targeted to affected children.

Table 1 Socio-demographic characteristics of the children according to HIV status.

\begin{tabular}{|c|c|c|c|c|}
\hline Characteristics & HIV Infected $N=120(\%)$ & Non-HIV infected $\mathrm{N}=120(\%)$ Control & $\boldsymbol{x}^{2}$ & p-value \\
\hline \multicolumn{5}{|l|}{ Sex } \\
\hline Male & $58(48.3)$ & $66(55.0)$ & \multirow[t]{2}{*}{1.07} & \multirow[t]{2}{*}{0.30} \\
\hline Female & $62(51.7)$ & $54(45.0)$ & & \\
\hline \multicolumn{5}{|l|}{ Age (in years) } \\
\hline $2-5$ & $47(39.2)$ & $50(41.7)$ & - & - \\
\hline $6-11$ & $58(48.3)$ & $45(37.5)$ & - & - \\
\hline $12-15$ & $15(12.5)$ & $25(20.8)$ & 0.67 & 0.88 \\
\hline Mean \pm SD & $7.40 \pm 3.27$ & $6.85 \pm 3.70$ & - & - \\
\hline \multicolumn{5}{|c|}{ Place of Residence } \\
\hline Urban & $55(45.8)$ & $16(13.3)$ & \multirow[t]{2}{*}{30.41} & \multirow[t]{2}{*}{0.001} \\
\hline Rural & $65(54.2$ & $104(86.7)$ & & \\
\hline
\end{tabular}

\section{Materials and Methods}

The study was a cross-sectional case control study conducted in the Nnamdi Azikiwe University Teaching Hospital Nnewi North Local Government Area (NNLGA) of Anambra State. Nnewi, the host town of NAUTH is the second largest town in Anambra state, with a population of 233,658 based on the Nigerian 2006 census figures [25]. The inhabitants are predominantly Igbos. Majority of them are traders and Christianity are the dominant religious belief. Nnamdi Azikiwe University Teaching Hospital is a referral center for treatment of HIV infected patients (including children) for the South East geopolitical zone of Nigeria.
The study population was HIV positive and HIV negative children attending the Pediatrics section of HIV clinic and Pediatrics out patient's clinics respectively at Nnamdi Azikiwe University Teaching Hospital, Nnewi. Both old and new patients from the HIV out patient's clinic were recruited. The Pediatrics HIV Clinic has a total of about 900 registered patients from January 2005 to December 2012. An average of two new cases is enrolled per week and about 40-50 patients are seen during each clinic session. The average number of Pediatrics patients attending the out-patient's department per week is about 200 patients per week. Children aged two to fifteen years (last birth day) attending Pediatrics HIV Clinic in Nnamdi Azikiwe University Teaching Hospital were recruited into the study. 
HIV negative children attending NAUTH children outpatient clinic within the same age range served as controls after being properly screened for HIV. Pre-test counseling was done prior to the screening by the researchers. All those confirmed negatives from the children's outpatient clinic were enrolled as control while those that tested HIV positive were recruited into the study and subsequently referred to HIV clinic for management.

\section{Statistical Analysis}

Two design strategies were followed in the statistical analyses in this study, descriptive and analytic. The frequency distribution tables, mean, standard deviation and histogram were components of descriptive variables. Analytic method was observational which involved comparing a test between a case group and a control group.

\section{Results}

A total of 240 children comprising 120 children with HIV infection and 120 without HIV infection were studied. Among the HIV infected children girls were more (51.7\%) in number whereas among the non-infected controls boys predominated (55.0\%). The difference, however was not statistically significant $\left(\chi^{2}=1.07, p=0.30\right)$ shown in Table 1 and Figure 1.

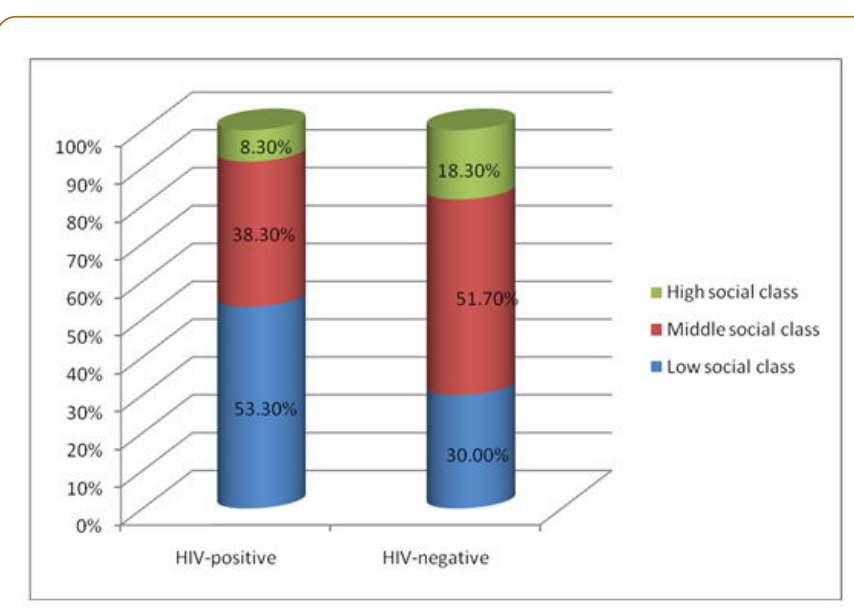

Figure 1 Distribution of the children according to their socio-economic status.

The mean age of the children with HIV was slightly higher (7.40 \pm 3.27 years) compared to the mean age of those not infected with HIV $(6.85 \pm 3.70$ years). Most of the children studied were from the rural areas, a greater proportion of those who were HIV positive were from the urban areas. The observed difference is statistically significant $\left(\chi^{2}=30.41\right.$, $\mathrm{p}<0.001$ ).

Majority of children who were HIV infected were of lower socio-economic class (53.3\%), while most of those who were not infected were of middle or high social class (70.1\%). HIV infected children were more likely to be of the lower socio- economic class than those who were not infected $\left(\varkappa^{2}=14.91\right.$, $p=0.01)$.

A slightly higher proportion of children (60.0\%) without HIV infection compared to those with HIV infection (56.7\%) were vaccinated against $\mathrm{HBV}$, however this was not statistically significant $\left(\varkappa^{2}=0.33, p=0.85\right)$ (Figure 2).

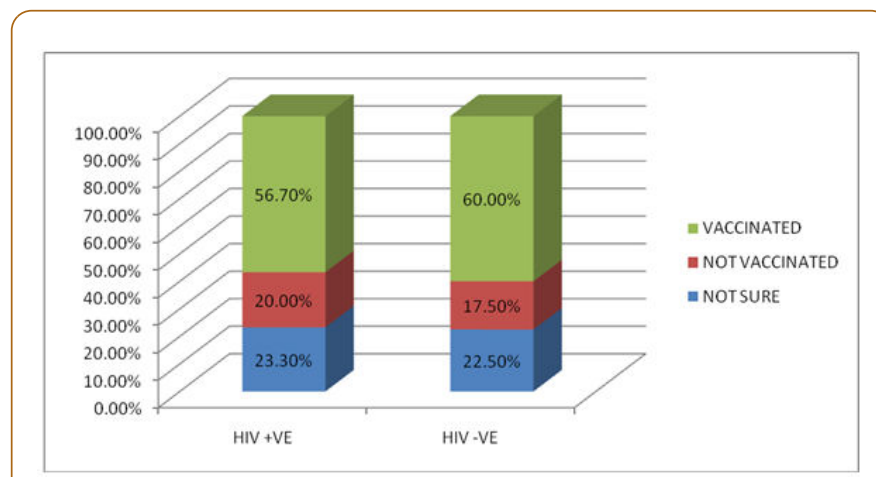

Figure 2 Distribution of subjects according to HBV vaccination status.

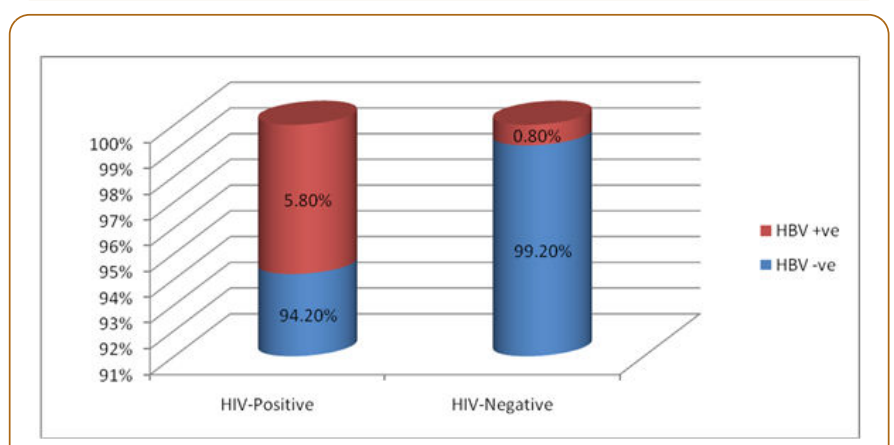

Figure 3 Prevalence of HBV seropositivity among HIVinfected and non-HIV infected children.

Figure 3 shows the HBV seroprevalence of the children according to their HIV status. The prevalence of HBV seropositivity was significantly higher among HIV-positive children compared to HIV- Figure negative ones (5.8\% versus $0.8 \%, p=0.03$ ).

The Hepatitis B-associated risk factors the patients were exposed to are as shown in Table 2 below. There are seven risk factors mentioned. The most commonly occurring risk factors include; Circumcision, Ear piercing, Scarification, Blood transfusion and Parenteral injection. When compared to noninfected children, the HIV infected subjects shared increased exposure to more exposed to blood transfusion $(30.8 \%$ vs. $5.0 \%)$, history of surgery $(5.0 \%$ vs. $2.5 \%)$, history of parenteral injection (6.7\% vs. $0.8 \%$ ) and scarification ( $22.5 \%$ vs. $16.7 \%)$. The chance of receiving blood transfusion was significantly higher among those who were HIV positive $\left(\varkappa^{2}=27.22\right.$, $\mathrm{p}<0.001)$. Moreover, HIV positive children were also at significantly increased risk of exposure to parenteral injection compared to HIV negative children $(0.8 \%)$. Only $3.3 \%$ children 
without HIV infection reported history of contact with jaundice patient.

Table 2 Distribution of risk factors for hepatitis B virus among the children by HIV status.

\begin{tabular}{|c|c|c|c|c|}
\hline Risk Factors & HIV Infected N=120 (\%) & Non-HIV infected $\mathrm{N}=120(\%)$ & $\boldsymbol{x}^{2}$ & p-value \\
\hline \multicolumn{5}{|l|}{ Ear piercing } \\
\hline Yes & $59(49.2)$ & $63(52.5)$ & 0.15 & 0.69 \\
\hline No & $61(50.8)$ & $57(47.5)$ & - & - \\
\hline \multicolumn{5}{|c|}{ History of blood transfusion } \\
\hline Yes & $37(30.8)$ & $6(5.0)$ & 27.52 & $<0.001$ \\
\hline No & $83(69.2)$ & $114(95.0)$ & - & - \\
\hline \multicolumn{5}{|c|}{ History of surgery } \\
\hline Yes & $6(5.0)$ & $3(2.5)$ & 0.46 & 0.50 \\
\hline No & $114(95.0)$ & $117(97.5)$ & - & - \\
\hline \multicolumn{5}{|l|}{ Circumcision } \\
\hline Yes & $61(50.8)$ & $67(55.8)$ & 0.52 & 0.42 \\
\hline No & $59(49.2)$ & $53(44.2)$ & - & - \\
\hline \multicolumn{5}{|c|}{ History of parenteral injection } \\
\hline Yes & $112(93.8)$ & $119(99.2)$ & 4.16 & 0.02 \\
\hline No & $8(6.7)$ & $1(0.8)$ & - & - \\
\hline \multicolumn{5}{|c|}{ History of contact with jaundiced patients } \\
\hline Yes & $0(0.0)$ & $4(3.3)$ & - & - \\
\hline No & $120(100.0)$ & $116(96.7)$ & - & - \\
\hline \multicolumn{5}{|l|}{ Scarification } \\
\hline Yes & $27(22.5)$ & $20(16.7)$ & 1.30 & 0.26 \\
\hline No & $93(77.5)$ & $100(83.3)$ & - & - \\
\hline
\end{tabular}

Table 3 Association between Socio-demographic characteristics and HBV serostatus among HIV infected children.

\begin{tabular}{|c|c|c|c|c|}
\hline Characteristics & Hepatitis Negative $\mathrm{N}=113(\%)$ & Hepatitis Positive $\mathrm{N}=7$ (\%) & $x^{2}$ & p-value \\
\hline \multicolumn{5}{|l|}{ Sex } \\
\hline Male & $51(46.0)$ & $6(85.7)$ & \multirow[t]{2}{*}{4.16} & \multirow[t]{2}{*}{0.06} \\
\hline Female & $61(54.0)$ & $1(14.3)$ & & \\
\hline \multicolumn{5}{|l|}{ Age (in years) } \\
\hline $2-5$ & $47(39.2)$ & $0(0.0)$ & - & - \\
\hline $6-11$ & $55(48.3)$ & $3(42.9)$ & - & - \\
\hline $12-15$ & $11(12.5)$ & $4(57.1)$ & - & - \\
\hline Mean Age $\pm S D$ & $7.1 \pm 3.1$ & $11.9 \pm 1.7$ & 3.94 & $<0.001$ \\
\hline \multicolumn{5}{|c|}{ Place of Residence } \\
\hline Urban & $52(46.0)$ & $3(42.9)$ & \multirow[t]{2}{*}{0.03} & \multirow[t]{2}{*}{1.00} \\
\hline Rural & $61(54.0)$ & $4(57.1)$ & & \\
\hline
\end{tabular}


Table 3 shows the relationship between socio-demographic characteristics and hepatitis B seropositivity among HIV infected children. Majority of the HIV infected children (85.7\%) with hepatitis $B$ infection were male, and the mean age of those infected $11.9 \pm 1.7$ years was significantly higher than the mean age of those without hepatitis B infection $(7.1 \pm 3.1$ years, $t=3.94, p<0.001)$. Also, more children from the rural area $(57.1 \%)$ were infected than those from urban area (42.9\%).

\section{Discussion}

The finding in this study of a higher prevalence of Hepatitis B surface antigen among HIV positive in comparison to negative children agrees with previous reports [26,27]. The higher prevalence of HBsAg in HIV infected could be attributed to the common mode of transmission, the decrease rate of HBsAg clearance in HIV- positive children because of the associated immune suppression [28]. This is in addition to the higher incidence of risk factors such as scarification, surgery and increased frequency of blood transfusion and parenteral injections among HIV-infected children as found in this study.

While the prevalence rate of HBV obtained among HIV negative $(0.8 \%)$ in this study is comparable to findings of an Ibadan [29] study (0.5\%) that used similar method of assay it is however, lower than the reports from other studies [30,31]. This may be related to differences in population characteristics such as exposure to risk factors, socioeconomic status, HBV immunization rates and methods of assay. Among HIV- positive children, studies that used ELISA assay methods reported higher prevalence rates than the $5.8 \%$ found in this study; $7.7 \%$ in Benin, $19 \%$ in Maiduguri [32] and $12 \%$ in Cote d'Ivoire [33]. Other researchers have made similar observations $[34,35]$.

The prevalence of $5.8 \%$ among HIV infected children in this study is also lower than $7.6 \%, 44.7 \%$ and $12.4 \%$ reported by Chukwuka et al. [20], Bukbuk et al. [21], and by Alikor and Erhabor [36] respectively. The lower prevalence in this study could be attributed to increasing availability of HBV vaccine which is now included in the National Programme on Immunization in Nigeria. Hepatitis $B$ virus vaccine has been proven to reduce the prevalence of HBV even among HIV positive population [37]. The low prevalence of HBV in this study could also be due to the current increased awareness of HIV and health education concerning preventive methods particularly the observation of universal precaution.

The finding in this study was that HBV infection is more in older children with HIV. This is consistent with those of Bukbuk et al. [21] and Zhou et al. [37]. On the contrary, Narcissi et al. and Teletela et al. [38] documented no association between age and HBV/HIV co-infection. Moreover, the older age groups have cumulative risk for exposure to HBV infections as the years get advance [39].

None of the children aged 0-6 years had HBV infection in both the study group and the controls; this could be attributed to the Hepatitis $B$ vaccine in-cooperated into childhood immunization programme at birth in Nigeria. This assertion is supported by a study in China [37]. However; the smaller sample size of subjects within the age group might also have influenced this finding.

In the study, gender analysis revealed that $\mathrm{HBsAg}$ seropositivity was not significantly higher in males than in the females in both HIV-infected and non-HIV infected. This is in contrast with earlier findings by Otegboye et al. [40] and Mehmet et al. [41]. Their observations may be due to predisposition of boys to more aggressive sports and plays might likely result in injuries and bleeding [42].

Concerning HBV risk factors and seropositivity, significantly higher HBsAg seropositives were seen among the HIV-infected children who received parenteral injection. A good number of children received parenteral injections from patent medicine dealers and maternity homes and majority of affected children belong to the middle and lower socioeconomic. This finding is consistent with those reported by other researchers in their various studies [43-46].

\section{Conclusion}

The findings of this study also demonstrated the role of blood transfusion in HBV transmission. Among the HIVpositive children, previous history of blood transfusion was significantly associated with HBV infection. In all these cases the blood was donated by relatives and was reportedly screened for HBV. This finding is in agreement with several other epidemiological studies, which found blood transfusion to be a major route for HBV transmission. The risk of HBV from transfusions of screened blood has been attributed to blood donated during HBV window period, poor test kit sensitivity, false negative results and laboratory errors. It has been found that blood donated by close relative pose a greater risk for transmission of HBV than the professional donors whose negative HBV status is known to the laboratories.

1. HIV-infected children had a significantly higher prevalence of HBsAg compared to non-HIV infected children.

2. Most of the children with HBV infection were HIV positive and aged $10-15$ years.

3. Prevalence of $\mathrm{HBsAg}$ was significantly associated with unsafe parenteral injection.

4. Blood transfusion was significantly associated with HBV carriage among HIV infected.

\section{Ethical Approval and Consent}

Ethical approval for the study was obtained from the Ethics Committee of the Nnamdi Azikiwe University Teaching Hospital Nnewi. Written consent was obtained from caregivers after informing them on the need and benefits of the study. Assent was obtained from older children.

\section{References}

1. Wiessing L, Ferri M, Grady B, Kantzanou M, Sperle I, et al. (2014) Hepatitis $C$ virus infection epidemiology among people who 
inject drugs in Europe: A systematic review of data for scaling up treatment and prevention. PloS one 9: e103345.

2. Lavanchy D (2004) Hepatitis B virus epidemiology, disease burden, treatment, and current and emerging prevention and control measures. J Viral Hepat 11: 97-107.

3. Marrero CR, Marrero JA (2005) Viral hepatitis and hepatocellular carcinoma. Arch Med Res 38: 612-620.

4. Seeger C, Mason WS (2000) Hepatitis B virus biology. Microbio Mol Biol Rev 64: 51-68.

5. Kramvis A, Kew MC (2007) Epidemiology of hepatitis B virus in Africa, its genotype and clinical associations of genotypes. Hepatol Res 37 (S1).

6. Kew MC (2010) Epidemiology of chronic hepatitis B virus infection, hepatocellular carcinoma and hepatitis $B$ virusinduced hepatitis B virus induced hepatocellular carcinoma Pathol Biol(paris) 58:273-277.

7. Fakunle YM, Abdulrahman MB, Whittle AC (1981) Whittle AC, Hepatitis $B$ virus infection in children and adults in Northern Nigeria: A preliminary survey. Trans R Soc Trop Med Hyg 75: 626-698.

8. Ukaeje CJ, Ogbu O, Inyama PU (2005) Prevalence of hepatitis B surface antigen among blood donors and human immunodeficiency virus infected patient in Jos, Nigeria. Mem Inst Oswaldo Cruz 100: 13-16.

9. Jibrin B, Jiya NM, Ahmed H (2014) Prevalence of hepatitis B surface antigen in children with sickle cell anemia. J Trop Pediatr 44: 376-377.

10. Abiodun PO, Flach KH Omoike IU (1986) Hepatitis and sickle cell anaemia. Niger J Paed 13: 95.

11. USAID Health (2013) HIV/AIDS, Global AID Report (accessed 2014 August 20). Available from http://www.usaid.gov/whatwe-do/global.health.

12. National Agency for the control of AIDS (2013-2015) United Nations General Assembly Special Session UNGASS Country Progress Report Nigeria 2014-2015 Abuja; FMOH: 2012 (accessed December 2014). Available from sbccvch.naca.gov.ng/

13. NARHS (2013) National HIV/AIDS and reproductive Health survey (accessed December 2013). Available from http:// www.unaids.org.

14. United Nations Children's Fund (2011) State of the World's Children. New York: 2012. (Accessed 2013 Jan 5). Available from www.unicef.org/sowc2012/.../sowc-2012-Main-ReportEN-21Dec 2011.

15. Federal Ministry of Health (2014) National Guideline for $P$ aediatric HIV and AIDS treatment and care. Abuja, Nigeria.

16. Pouti M, Manno D, Nesta P, Carosi G (2008) Hepatitis B virus and HIV co-infection in low income countries: Unmet needs. Clin Infect Dis 461: 367-369.

17. Alter M (2006) Epidemiology of viral hepatitis and HIV coinfection. J Hepatol 44: S6-9.

18. Thio $C L$ (2003) Hepatitis $B$ in the human immunodeficiency virus-infected patient: Epidemiology, natural history, and treatment. Semin Liver Dis 23: 125-136.

19. World health Organization (2001) Introduction of Hepatitis B into Childhood Immunization Services. Management Guidelines, including Information for Health Workers and Parents. WHO, Geneva.
20. Chukwuka JO, Ezechukwu CC, Okoli CC (2004) Prevalence of hepatitis B surface antigen in primary school children in Nnewi, Nigeria. Niger J Clin Pract 7: 8-10.

21. Bukbuk DN, Barsi AP, Mungoro ZM (2005) Seroprevalence of hepatitis $B$ surface antigen among primary school in rural Hawal valley, Borno state, Nigeria. Niger J Comm Med Pri Health Care 17: 20-23.

22. Sadoh AE, Sadoh WE, Iduoriyekenwen NJ (2011) HIV co-infection with Hepatitis B and C viruses among Nigerian children in antiretroviral treatment programme. S Afr J Child Health 5: 7-10.

23. Colin JF, Cazals-Hatem D, Loriot MA, Pham BN, Auperin A, et al. (1999) Influence of human immunodeficiency virus infection on chronic hepatitis B in homosexual men. Hepatology 29: 1306-1310.

24. Gilson RJ, Hawkins AE, Beecham MR, Briggs $M$, Waile J, et al. (1997) Interactions between HIV and HBV in homosexual men. AIDS 11: 597-606.

25. Anambra state Government/UN-HABITAT. Executive summary of structure plans for Onitsha, Awka and Nnewi and environs 2009-2027. UN-HABITAT; 2009. Accssed 2014 Jan. 19, Available from:http://www.unhabitat.org.

26. Bojuwoye BJ (1997) The burden of viral hepatitis in Africa. West. Afr J Med 16: 198-203.

27. Zaki H, Darmstadt GL, Baten A, Ahsan CR, Saha SK (2003) Seroepidemiology of hepatitis $B$ and delta virus infections in Bangladesh. J Trop Pediatr 49: 371-374.

28. Centres for Disease Control and Prevention (2009) Guidelines for prevention and treatment of opportunistic infections in HIVinfected adults and adolescents: Recommendations from CDC, the National Institutes of Health, and the HIV Medicine Association of the Infections Diseases Society of America.

29. De-Vires-Sluijs TE, Hansen BE, Van-Doornum GJ, De-Man RA, Springeling $T$, et al. (2008) A prospective open study of the efficacy of high dose recombinant hepatitis $B$ rechallenges vaccination in HIV-infected patients. J Infect Dis 197: 292-294.

30. Cruciani M, Mengoli C, Serpelloni G, Lanza A, Gomma M, et al. (2009) Serologic response to hepatitis B vaccine with high dose and increasing number of injections in HIV infected adult patients. Vaccine 27: 17-22.

31. Ashir GM, Rabasa Al, Gofama MM, Bukbuk D, Abubukak H, et al. (2009) Study of hepatic functions and prevalence of hepatitis $B$ surface antigenaemia in Nigerian children with human immunodeficiency virus infection. Niger J Med 18: 260-262.

32. Route F, Chaix ML, Inowley A, Anaky MF, Fassiou P, et al. (2008) Frequent occurrence of chronic heptatits $B$ virus infection among west Africa HIV type-1-infectected children. Clin Infect DIS 46: 361-366.

33. Okonko IO, Okerentugba P, Innocient-Adiele H (2012) Detection of Hepatitis B surface Antigen ( $\mathrm{HBsAg}$ ) Among Children in Ibadan, Southwestern Nigeria. Int J Infect Dis 10.

34. Laskar MS, Harada N, Khan F (1997) Prevalence of hepatitis B surface antigen ( $\mathrm{HBsAg}$ ) in vigarunnessa noon girls school children in Dhaka, Bangladesh. Cent Eur J Public Health 5: 202-204.

35. Alikor EA, Erhabor ON (2007) Seroprevalence of hepatitis B surface antigenaemia in children in a tertiary institution in the Niger Delta of Nigeria. Niger J Med 16: 250-251. 
36. Zhou S, He Y, Li H, Dou Z, Bulterys M, et al. (2010) Hepatitis B and hepatitis $C$ sero-prevalence in children receiving antiretroviral therapy for human immunodeficiency virus-1 infection in China. J Acquir Immune Defic Syndr 2: 191-196.

37. Biggar RJ, Ortiz-Conde BA, Bagni RK, Bakaki PM, Wang CD, et al. (2006) Hepatitis $C$ virus genotype 4 in Ugandan children and their mothers. Emerg Infect Dis 2006 12: 1440.

38. Mustapha SK, Jibrin YB (2004) The prevalence of hepatitis B surface antigenaemia in patients with Human Immunodeficiency virus infection in Gombe, Nigeria. Ann Afri Med 4: 10-11.

39. Otegboye JA, Taiwo BO, Akingbola JS, Odaibo GN, Adedapo KS, et al. (2008) Prevalence of hepatitis $B$ and $C$ seropositivity in a Nigeria cohort of HIV-infected patient. Ann Hepatol 7: 152-156.

40. Yao JL (1996) Perinatal transmission of hepatitis B virus infection and vaccination in China. Gut 38: S37-38.

41. Denue AB, Ajayi B, Abja UA, Bukar AA, Akawu C, et al. (2012) A survey of hepatitis $B$ and $C$ virus prevalence in human immunodeficiency virus positive patients in the tertiary health institution in the North-Eastern Nigeria. Int J Med Sci 4: 13-18.

42. Ugwuja E, Ugwu N (2010) Sero-prevalence of Hepatitis B surface antigen and liver functions test among Adolescents in Abakaliki, South Eastern Nigeria. Int J Trop Med 6: 42.

43. Agbede OO, Isienyi OJ, Kolawole M, Ojuawo A (2007) Risk factors and sero-prevalence of hepatitis $B$ surface antigen in mothers and their preschool age children in Ilorin, Nigeria. Therapy 4: 67-72.

44. Maddawa V, Burgess C, Drucker E (2002) Epidemiology of chronic hepatitis $C$ infection in Sub-Saharan African. Lancet Infect. Dis 2: 293-302.

45. Halim NKD, Ajayi OI (2000) Risk factors and sero-prevalence of hepatitis $\mathrm{C}$ antibodies in blood donors in Nigeria. East African Med J 77: 410-412.

46. Ogbu O, Uneke CJ (2009) Hepatitis B virus and blood Transfusion safety in Sub-Saharm Africa. Int J Dis 7: 2. 